\title{
Pengaruh Kualitas Pelayanan dan Biaya Pelayanan Jasa Pernikahan Terhadap Kepuasan Masyarakat Pada KUA Kecamatan Cikampek Kabupaten Karawang
}

\author{
Dedi Mulyadi \\ dedi.mulyadi@ubpkarawang.ac.id
}

\begin{abstract}
ABSTRAK
Penelitian ini bertujuan untuk mengetahui seberapa besar pengaruh kualitas pelayanan dan biaya pelayanan jasa terhadap kepuan masyarakat pada KUA Kecamatan Cikampek Kabupaten Karawang. Penelitian ini dilakukan berdasarkan metode deskriptif dan verifikatif. Populasi dalam penelitian ini adalah pengantin Kecamatan Cikampek yang menikah di luar kantor KUA dengan menggunakan pelayanan jasa pernikahan langsung dari KUA Kecamatan Cikampek berjumlah 67 pasangan pengantin. Teknik sampling yang digunakan dalam penelitian ini adalah probability sampling. Hasil penelitian yang didapatkan dalam penelitian ini adanya hubungan asosiatif antara kualitas pelayanan dengan kepuasan masyarakat besarannya sebesar 0,313, adanya hubungan asosiatif antara biaya pelayanan jasa pernikahan dengan kepuasan masyarakat besarannya sebesar 0,453. Adapun besaran pengaruh total dari variabel bebas : kualitas pelayanan $\left(\mathrm{X}_{1}\right)$, biaya pelayanan jasa pernikahan $\left(\mathrm{X}_{2}\right)$ terhadap kepuasan masyarakat (Y) dinyatakan oleh besaran koefisien determinasi $\left(\mathrm{R}_{\mathrm{YX}}\right)^{2}$ sebesar 45,1\% sedangkan pengaruh variabel lain di luar model adalah sebesar 54,9\%. Untuk pengaruh parsial kualitas pelayanan $\left(\mathrm{X}_{1}\right)$ terhadap kepuasan masyarakat $(Y)$, nilai Sig. $(0,005)<\alpha(0,05)$ maka Ho ditolak. Dengan demikian dapat disimpulkan bahwa kualitas pelayanan secara parsial berpengaruh signifikan terhadap kepuasan masyarakat. Untuk pengaruh parsial biaya pelayanan jasa pernikahan $\left(\mathrm{X}_{2}\right)$ terhadap kepuasan masyarakat (Y), nilai Sig. $(0,000)$ $<\alpha(0,05)$ maka Ho ditolak. Dengan demikian dapat disimpulkan bahwa biaya pelayanan jasa pernikahan secara parsial berpengaruh signifikan terhadap kepuasan masyarakat. Nilai Sig. sebesar 0,000 yang lebih kecil dari $\alpha$ $(0,05)$. Dengan demikian Ho ditolak sehingga dapat disimpulkan bahwa kualitas pelayanan $\left(\mathrm{X}_{1}\right)$ dan biaya pelayanan jasa pernikahan $\left(\mathrm{X}_{2}\right)$ secara simultan berpengaruh signifikan terhadap kepuasan masyarakat $(\mathrm{Y})$.
\end{abstract}

Kata Kunci : Kualitas Pelayanan, Biaya Pelayanan Jasa, Kepuasan Masyarakat PENDAHULUAN

Sudah menjadi rahasia umum bahwa pelayanan di negeri ini memiliki konotasi yang negatif seperti lamban, mahal, dan banyaknya ketidakjelasan. Bagaimana perkembangan fungsi pelayanan aparat pemerintah selama hampir tiga belas tahun bergulirnya era reformasi adalah satu hal yang menarik untuk di bahas.

Sebagian berita mengenai pelayanan Publik setelah era reformasi adalah sebagaimana dinyatakan oleh Leo Agustino ( 2004 ) dalam El-Raihan ( 2007 ) menyampaikan hasil survey Center for Population and Policy Studies (CPPS) UGM menunjukkan perilaku aparatur birokrasi dalam memberikan pelayanan kepada masyarakat saat ini masih lebih berdasar pada 
rule driven. Artinya pelayanan publik yang diberikan kepada masyarakat terlalu barorientasi pada aturan-aturan, sehingga menyebabkan kekakuan-kekauan, kelambanan-kelambanan, serta ketidakpuasan kepada warga. Budaya rule driven ini sudah pasti tidak mendorong kreativitas aparatur birokrasi dalam memberikan pelayanan. Selanjutnya pelayanan Publik juga dinilai tidak efisien dalam bekerja, sehingga banyaknya pungutan liar yang membengkakkan biaya riil suatiu pelayanan.

Budiman dari UNY Yogyakarta dalam tulisannya yang dimuat dalam jurnal efisiensi on line vol VI No.1 Pebruari 2006 mengemukakan bahwa pelayanan Publik ini masih buruk, lamban, penuh pungli dan inefisiensi. Hal ini mudah bagi masyarakat untuk menilai karena rakyat langsung merasakannya.

Dengan kata lain pelayanan yang baik sebagai perwujudan kinerja birokrasi relatif harus berdasar pada kepuasan dan apa yang dibutuhkan masyarakat. Penyelenggaraan pemerintahan atau kinerja birokrasi juga harus memiliki responsivitas yang tinggi. Birokrasi publik sebagai organisasi publik harus memiliki kemampuan untuk tanggap dalam mengenali kebutuhan masyarakatnya. Efisiensi pelayanan harus dapat diwujudkan dalam bentuk pelayanan yang tidak berbelit-belit, adanya perbandingan yang proporsional antara apa yang harus dikorbankan oleh warga dan pelayanan yang didapatkan. Masalah korupsi yang merupakan penyakit yang tidak kunjung sembuh dari dalam tubuh birokrasi, harus benar-benar diberantas, untuk mewujudkan birokrasi yang bersih, kendati untuk melakukan reformasi kearah kinerja birokrasi yang akuntabel, responsif, efisien dan tidak korup bukanlah sesuatu yang mudah.

Ternyata berita-berita di atas menunjukkan bahwa setelah era reformasi digulir di negeri ini, kualitas pelayanan Publik masih jauh dari memuaskan dan cenderung buruk. Pelayanan Kementerian Agama RI yang keberadaannya diwakili oleh Kantor Urusan Agama (KUA) pada setiap wilayah Kecamatan diharapkan mencerminkan kualitas pelayanan Publik yang memuaskan.

Kantor Kementerian Agama Kabupaten Karawang mempunyai visi dan misi berdasarkan Keputusan Menteri Agama ( KMA ) No. 489 tahun 2000. Visi Kementerian Agama adalah menjadikan Agama sebagi pelopor etika berbangsa, inspirator pembangunan dan motivasi bagi terciptanya toleransi beragama dan visi Kantor Kementerian Agama Kabupaten Karawang adalah menjadikan agama sebagai landasan etika kehidupan bermasyarakat dan pembangunan daerah Kabupaten Karawang untuk maju, tangguh dan sejahtera. Adapun misi Kementerian Agama adalah meningkatkan penghayatan moral, 
kedalam spiritual dan etika keagamaan serta penghormatan atas keanekaragaman keyakinan keagamaan, melalui peningkatan kualitas pendidikan agama di sekolah umum dan perguruan agama, pengembangan kehidupan keluarga sakinah, peningkatan kualitas pelayanan ibadah keagamaan dalam proses pembangunan sera memperkokoh kerukunan umat beragama atas dasar rasa saling hormat dan kerelaan bersama.

Standar pelayanan prima pernikahan KUA Kec. Cikampek Kab.Karawang berdasarkan Keputusan Menteri Agama ( KMA ) Nomor 477 Tahun 2004 atau yang dikenal dengan P5.

Standar pelayanan pernikahan di atas tadi belum sepenuhnya dilaksanakan sesuai dengan yang diharapkan dikarenakan penyetoran biaya Nikah oleh catin ke Bank/ Kantor Pos tidak berjalan efektif, karena secara umum catin merasa keberatan harus menyetor langsung biaya Nikah, hal ini mengingat penyetoran hanya di BRI,BNI Cabang dan Kantor Pos Besar yang bertempat di Karawang yang jaraknya cukup jauh dari KUA, pelaksanan penataran Catin belum maksimal karena banyak para catin yang bekerja tidak mendapat izin dari perusahan tempat bekerja, pendaftaran belum semua memanfaatkan tenggang waktu 10 hari kerja, Karena kurangnya kesadaran masyarakat.

Hal ini dilandasi oleh keadaan nyata pada pelaksanaan pelayanan Publik di KUA Kecamatan Cikampek. Secara umum yang diamati melalui observasi awal ada dua hal yaitu: Pertama, masih banyak ditemui di masyarakat Kecamatan Cikampek yang tidak mau berurusan langsung dengan pelayanan KUA di Kecamatan Cikampek. Mereka masih mengandalkan pihak ketiga dalam urusan dengan KUA. Tentu saja hal ini menimbulkan pertanyaan, kenapa masih banyak masyarakat Kecamatan Cikampek yang tidak mau berurusan langsung dengan KUA. Faktor-faktor apa saja yang menyebabkan masyarakat enggan melakukan hubungan langsung dengan KUA Kecamatan Cikampek. Berdasarkan observasi awal diperoleh informasi bahwa faktor keengganan masyarakat disebabkan oleh ketidaktahuan dan ketidakjelasan prosedur pelayanan pernikahan. Seperti bagaimana cara untuk memulai pendaftaran, bagaimana langkah setelah pendaftaran, dokumen apa saja yang dibutuhkan untuk pendaftaran, dan berapa besar biaya perkawinan yang harus dikeluarkan saat nikah di luar kantor KUA. Kedua, ketidakjelasan biaya pelayanan jasa pernikahan yang harus dikeluarkan oleh setiap masyarakat pengguna jasa pernikahan terutama saat melaksanakan prosesi pernikahan di luar kantor KUA dan di luar jam kerja KUA. Kebanyakan masyarakat tidak mengetahui berapa sesungguhnya biaya resmi yang harus dikeluarkan dalam penggunaan jasa tersebut. Ketidakjelasan ini juga menimbulkan rasa tidak puas dari sebagian masyarakat yang 
menganggap biaya yang harus dikeluarkan oleh mereka terlalu mahal. Oleh karena itu pihak KUA harus melakukan langkah-langkah sosialisasi untuk menjernihkan permasalahan ini.

Untuk menjawab permasalahan di atas, perlu dilakukan penelitian secara lebih komprehensif lebih dahulu mengenai bagaimana kualitas pelayanan dan biaya pelayanan jasa pernikahan di KUA Kecamatan Cikampek. Hal ini penting untuk dijadikan sumber rujukan bagi instansi pemerintah terkait, yaitu Kementerian Agama. Secara ideal selanjutnya kedua hal tersebut dicari tahu apakah mampu memberikan dampak terhadap tingkat kepuasan masyarakat,

Kualitas pelayanan ini bisa dilihat dari teori Zeithaml (1988) yaitu dengan mempertimangkan 5 faktor. Faktor utama adalah tangible atau sarana fisik, kedua adalah realibility atau keandalan untuk menyediakan pelayanan, ketiga adalah responsipnis atau kesanggupan memberikan pelayanan cepat dan tepat, yang keempat adalah assurance atau keramahan dan sopan santun yang meyakinkan kepercayaan konsumen, dan yang kelima adalah empathy atau sikap penuh perhatian terhadap konsumen. Berdasarkan kajian awal yang dikaitkan dengan teori Zeithaml (1988), maka kualitas pelayanan di KUA memiliki permasalahan dalam aspek tangible atau sarana kerja yang masih belum optimal, realibility atau perhatian pegawai terhadap masyarakat yang belum optimal dan assurance atau kekurang mudahan pegawai untuk dihubungi.

Sementara itu berhubungan dengan biaya suatu pelayanan mengacu pada konsep Kotler (2009:68) yang melihat 4 faktor penting dalam harga pelayanan yaitu moneter, waktu, tenaga, dan psikis. Penetapan harga dalam pelayanan publik yang dilakukan oleh pemerintah menurut Kotler (2009:72) seharusnya juga didasarkan oleh pertimbangan sosial ekonomi masyarakat sebagai konsumennya. Berdasarkan konsep inilah dicoba diukur biaya pelayanan jasa pernikahan yang diberikan oleh KUA kecamatan Cikampek.

Tingkat kepuasan masyarakat dalam penelitian ini mengutip dari Giese dan Cote (2000) yang menjelaskan pendapat Oliver (1997) bahwa definis kepuasan konsumen mengacu pada literatur emosi. Dalam konsep ini dijelaskan bahwa semua orang mengetahui arti kepuasan konsumen adalah sampai diminta untuk memberikan definisi. Lebih lanjut Giese dan Cote (2000) juga menyampaikan definisi lain dari Codote, Woodreff, Jenkins, Holstead, Hortman, dan Schmidt bahwa kepuasan konsumen juga berarti melihat respon efektif dari konsumen. Atas dasar inilah maka konsep kepuasan masyarakat dinilai. Maka dapat disimpulkan bahwa penelitan berkaitan dengan pelayanan publik pada KUA Kecamatan Cikampek sangat perlu 
dilakukan karena hingga saat ini belum ditemukan penelitian yang terkait dengan permasalahan ini pada KUA Kecamatan Cikampek

Berdasarkan pemaparan yang telah dijelaskan peneliti tertarik untuk mengadakan penelitian dengan judul "Pengaruh Kualitas Pelayanan dan Biaya Pelayanan Jasa Pernikahan Terhadap Kepuasan Masyarakat Pada KUA Kecamatan Cikampek Kabupaten Karawang.

\section{METODE PENELITIAN}

Penelitian ini dilakukan berdasarkan metode deskriptif dan verifikatif. Metode deskriptif adalah suatu metode dalam meneliti status kelompok manusia suatu obyek, suatu set kondisi, suatu sistem pemikiran ataupun suatu kelas peristiwa pada masa sekarang. Menurut Travers (1978) dalam Husein Umar (2009 : 22) metode ini bertujuan untuk menggambarkan sifat sesuatu yang tengah berlangsung pada saat riset dilakukan dan memeriksa sebab-sebab dari suatu gejala tertentu. Metode Verifikatif digunakan untuk mengetahui hubungan antar variabel melalui pengujian hipotesis.

Metode deskriptif pada penelitian ini termasuk juga penelitian desktiptif Riset Korelasi menurut Consuelo (1988) dalam Husein Umar (2009 : 25) adalah penelitian yang dirancang untuk menentukan tingkat hubungan variabel-variabel bebas terhadap variabel terikatnya serta besarnya arah hubungan yang terjadi. Populasi, menurut Sugiono (2007:90), adalah wilayah generalisasi yang terdiri atas obyek/subyek yang mempunyai kualitas dan karakteristik tertentu yang ditetapkan oleh peneliti untuk dipelajari dan kemudian ditarik kesimpulannya. Populasi dalam penelitian ini adalah pengantin Kecamatan Cikampek yang menikah di luar kantor KUA dengan menggunakan pelayanan jasa pernikahan langsung dari KUA Kecamatan Cikampek. Teknik sampling yang digunakan dalam penelitian ini adalah probability sampling yaitu teknik sampling yang memberikan peluang yang sama bagi setiap unsur (anggota) populasi untuk dipilih sebagai sampel. Sedangkan metode pengambilan sampel yang digunakan simple random sampling, karena pengambilan anggota sampel dari populasi dilakukan secara acak tanpa memperhatikan strata yang ada dalam populasi itu. Adapun rancangan analisis untuk penelitian ini dengan menggunakan metode kuantitatif dilakukan untuk mengukur suatu fenomena penelitian dengan menggunakan alat bantu statistik. Adapun metode statistik yang digunakan untuk menganalisis hubangan antar variabel yang diteliti yaitu dengan menggunakan analisis jalur (path analisys) untuk menguji pengaruh secara parsial (individual) dan simultan (keseluruhan) dari variabel bebas (Independent) atau disebut variabel Eksogen terhadap variabel terikat (Dependent) atau disebut variabel endogen. 
Melalui analisis jalur ini akan dapat ditemukan jalur mana yang paling tepat dan singkat suatu variabel independen menuju variabel dependen yang terakhir dan juga untuk menganalisis pola hubungan antar variabel dengan tujuan untuk mengetahui pengaruh langsung maupun tidak langsung seperangkat variabel bebas (eksogen) terhadap variabel terikat (endogen). Setelah dihitung dengan menggunakan statistik, hasil dari perhitungan kemudian dianalisis dengan menggunakan metode kualitatif.

\section{HASIL PENELITIAN}

Data hasil penelitian yang didapatkan dalam penelitian ini adalah sebagai berikut :

\section{Besaran Hubungan Diantara Variabel - Variabel Bebas.}

Dalam analisis jalur, bahwa keterkaitan antara variabel - variabel bebas satu sama lainnya mempunyai keeratan hubungan yang berarti, dengan demikian dapat dihitung besaran pengaruh langsung maupun pengaruh tidak langsung. Untuk pengaruh tidak langsung merupakan perkalian antara koefisien jalur dengan koefisien korelasinya. Oleh karena itu terlebih dahulu dihitung masing - masing besaran koefisien korelasi di antara variabel bebas tersebut. Untuk lebih jelasnya hubungan antara kedua variabel bebas tersebut dapat dijelaskan pada gambar dibawah ini :

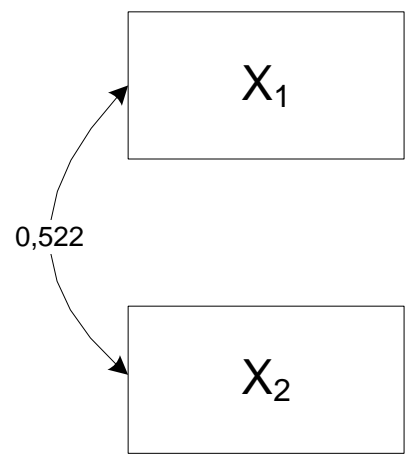

\section{Gambar 1 : hubungan di antara variabel bebas}

Kriteria keeratan hubungan antara variabel mengacu pada pendapat yang dikemukakan oleh Sevilla et. Al. (1977:280), yang menyatakan bahwa "high or low correlation, dependends generally on the nature of variables being studied. You may, how ever the following categorization which most specialist in statistics usually agree with". Secara rinci keeratan kriteria korelasi adalah sebagai berikut :

Tabel 1

Keeratan hubungan

\begin{tabular}{|c|c|}
\hline Correlation (r) & Indication \\
\hline Between $\pm 0,80$ to 1,00 & High correlation \\
\hline
\end{tabular}




\begin{tabular}{|c|c|}
\hline Between $\pm 0,60$ to 0,79 & Moderately high correlation \\
\hline Between $\pm 0,40$ to 0,59 & Moderatly correlation \\
\hline Between $\pm 0,20$ to 0,39 & Low correlation \\
\hline Between $\pm 0,01$ to 0,19 & Negligible correlation \\
\hline
\end{tabular}

Sumber : Sevilla et. Al. (1977:280)

Dari hasil analisis diperoleh masing - masing besaran koefisien korelasi diantara variabel bebas yaitu hubungan antara variabel kualitas pelayanan $\left(\mathrm{X}_{1}\right)$ dengan biaya pelayanan jasa pernikahan $\left(\mathrm{X}_{2}\right)$ didapat nilai sebesar 0,522 yang berarti mempunyai tingkat hubungan yang cukup kuat dan searah karena nilainya positif.

\section{Pengaruh Secara Parsial X Terhadap Variabel Y.}

Pengaruh secara parsial variabel $\mathrm{X}$ yaitu kualitas pelayanan dan biaya pelayanan jasa pernikahan terhadap variabel Y yaitu kepuasan masyarakat dapat digambarkan seperti yang tampak dalam gambar 2 di bawah ini :

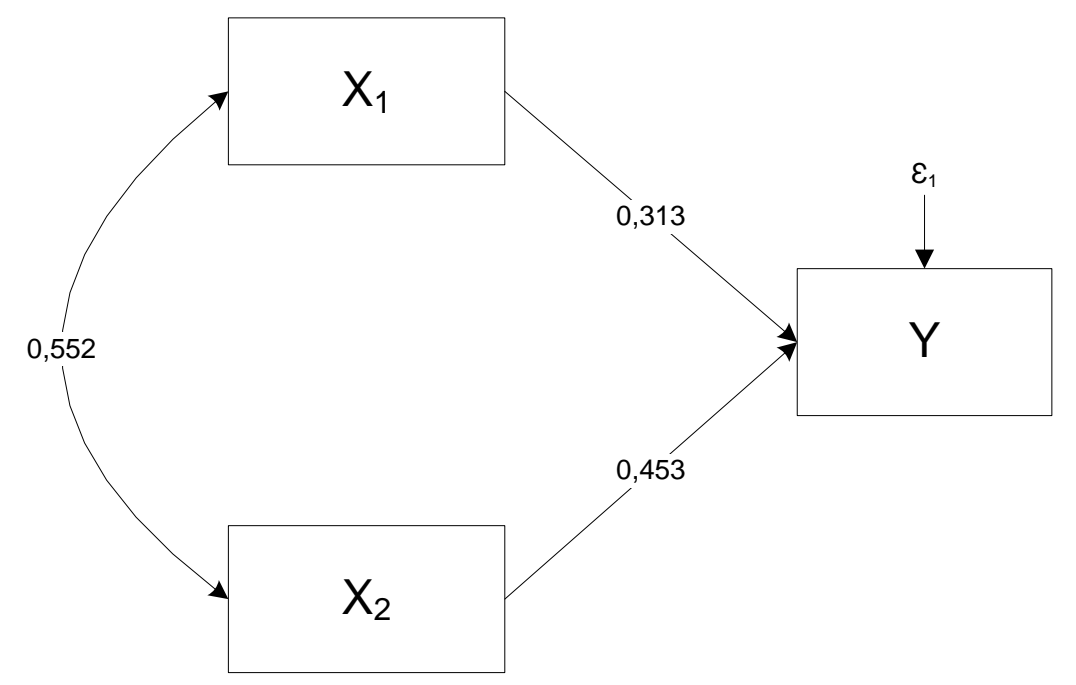

\section{Gambar 2 : Pengaruh Parsial Variabel Bebas (X) Terhadap Variabel Terikat (Y).}

Dari gambar di atas, dapat kita jelaskan besaran derajat asosiatif atau koefisien jalur dari masing - masing variabel bebas terhadap variabel terikat. Untuk jelasnya dapat dilihat pada tabel dibawah ini :

Tabel 2

Koefisien Jalur

\begin{tabular}{|c|c|}
\hline Variabel & Koefisien Jalur \\
\hline Kualitas pelayanan & 0,313 \\
\hline
\end{tabular}




\section{Sumber : Hasil Perhitungan Statistik}

Biaya pelayanan jasa pernikahan

0,453

Dari tabel tersebut dapat diperoleh bahwa biaya pelayanan jasa pernikahan mempunyai koefisien jalur tertinggi dibandingkan dengan variabel kualitas pelayanan.

Dari tabel 2 dapat diperoleh model jalur, yaitu :

$$
Y=0,313 X_{1}+\mathbf{0 , 4 5 3 X _ { 2 }}+\varepsilon_{1}
$$

Dimana :

$$
\begin{aligned}
& \mathrm{Y}=\text { Kepuasan masyarakat } \\
& \mathrm{X}_{1}=\text { Kualitas pelayanan } \\
& \mathrm{X}_{2}=\text { Biaya pelayanan jasa pernikahan } \\
& \boldsymbol{\varepsilon}_{1}=\text { Pengaruh variabel lain }
\end{aligned}
$$

Dari persamaan di atas dapat diartikan bahwa :

1. Adanya hubungan asosiatif antara kualitas pelayanan dengan kepuasan masyarakat besarannya sebesar 0,313 ( $\left.\rho_{\mathrm{YX} 1}\right)$.

2. Adanya hubungan asosiatif antara biaya pelayanan jasa pernikahan dengan kepuasan masyarakat besarannya sebesar 0,453 ( $\left.\rho_{\mathrm{YX} 2}\right)$.

\section{Pengaruh Bersamaan Variabel X Terhadap Variabel Y.}

Adapun pengaruh langsung dan tidak langsung secara bersamaan dari variabel kualitas pelayanan $\left(\mathrm{X}_{1}\right)$ dan biaya pelayanan jasa pernikahan $\left(\mathrm{X}_{2}\right)$ terhadap kepuasan masyarakat $(\mathrm{Y})$ adalah sebagai berikut :

\section{Besaran Pengaruh Langsung}

a. Pengaruh langsung variabel kualitas pelayanan $\left(\mathrm{X}_{1}\right)$ terhadap kepuasan masyarakat (Y) sebesar 9,8\% $\left(\rho^{2}{ }_{\mathrm{yx} 1}\right)$

b. Pengaruh langsung variabel biaya pelayanan jasa pernikahan $\left(\mathrm{X}_{2}\right)$ terhadap kepuasan masyarakat (Y) sebesar 20,5\% $\left(\rho_{\text {yх } 2)}^{2}\right.$

\section{Besaran Pengaruh Tidak Langsung}

a. Total Pengaruh tidak langsung variabel kualitas pelayanan $\left(\mathrm{X}_{1}\right)$ terhadap kepuasan masyarakat (Y) sebesar 7,4\%.

b. Total pengaruh tidak langsung variabel biaya pelayanan jasa pernikahan $\left(\mathrm{X}_{2}\right)$ terhadap kepuasan masyarakat (Y) sebesar 7,4\%.

Adapun besaran pengaruh total dari variabel bebas : kualitas pelayanan $\left(\mathrm{X}_{1}\right)$, biaya pelayanan jasa pernikahan $\left(\mathrm{X}_{2}\right)$ terhadap kepuasan masyarakat $(\mathrm{Y})$ dinyatakan oleh besaran 
koefisien determinasi $\left(\mathrm{R}_{\mathrm{YX}}\right)^{2}$ sebesar $45,1 \%$ sedangkan pengaruh variabel lain di luar model adalah sebesar $54,9 \%$.

Untuk lebih jelasnya, dapat dilihat dalam tabel dibawah ini :

Tabel : 3

Pengaruh Langsung dan Tidak Langsung Variabel X dan Y

\begin{tabular}{|c|c|c|c|c|c|}
\hline \multirow{2}{*}{ Variabel } & \multirow{2}{*}{$\begin{array}{c}\text { Pengaruh } \\
\text { Langsung ke Y }\end{array}$} & \multicolumn{2}{|c|}{$\begin{array}{c}\text { Pengaruh Tidak } \\
\text { Langsung }\end{array}$} & $\begin{array}{c}\text { Total Pengaruh } \\
\text { Tidak Langsung }\end{array}$ & $\begin{array}{c}\text { Total } \\
\text { Pengaruh }\end{array}$ \\
\cline { 3 - 4 } & 0,098 & - & 0,074 & 0,074 & $\mathbf{0 , 1 7 2}$ \\
\hline \hline $\mathbf{X}_{\mathbf{1}}$ & 0,205 & 0,074 & - & 0,074 & $\mathbf{0 , 2 7 9}$ \\
\hline $\mathbf{X}_{\mathbf{2}}$ & \multicolumn{7}{|c|}{ Total Pengaruh } & $\mathbf{0 , 4 5 1}$ \\
\hline \multicolumn{7}{|c}{}
\end{tabular}

Sumber : hasil olahan

Berdasarkan tabel di atas dapat menjelaskan bahwa besaran pengaruh dari masing masing variabel $X_{1}$ dan $X_{2}$ sebagai berikut :

1. Besaran pengaruh parsial variabel kualitas pelayanan $\left(X_{1}\right)$ baik pengaruh langsung maupun tidak langsung terhadap kepuasan masyarakat (Y) sebesar 17,2\%.

2. Besaran pengaruh parsial variabel biaya pelayanan jasa pernikahan $\left(\mathrm{X}_{2}\right)$ baik pengaruh langsung maupun tidak langsung terhadap kepuasan masyarakat (Y) sebesar 27,9\%.

\section{Pengujian Hipotesis Pengaruh Secara Parsial Variabel $X_{1}$ dan $X_{2}$ Terhadap Y}

Hasil uji statistik pengaruh variabel bebas $\left(\mathrm{X}_{1}, \mathrm{X}_{2}\right)$ terhadap variabel terikat $(\mathrm{Y})$ dengan menggunakan hipotesis :

$\mathrm{H}_{\mathrm{O}}: \rho_{\mathrm{YXi}}=0 \rightarrow$ tidak terdapat pengaruh secara parsial dari variabel independen (Xi) terhadap variabel dependen $\mathrm{Y}$.

$\mathrm{H}_{1} \quad \rho_{\mathrm{YXi}} \neq 0 \quad \rightarrow$ terdapat pengaruh secara parsial dari variabel independen $(\mathrm{Xi})$ terhadap variabel dependen $\mathrm{Y}$.

Dengan kriteria uji : Tolak Ho jika Sig. $<\alpha$ atau $t_{\text {hitung }}>t_{\text {tabel }}$

Tabel 4

Hasil analisis jalur secara parsial

\begin{tabular}{|c|c|c|c|c|}
\hline Struktural & $\begin{array}{c}\text { Koefisien } \\
\text { Jalur }\end{array}$ & $\mathbf{T}$ & Sig. & Kesimpulan \\
\hline
\end{tabular}




\begin{tabular}{|c|c|c|c|c|}
\hline$\rho_{Y X 1}$ & & & & $\begin{array}{c}\text { Ho ditolak, terdapat pengaruh } \\
\text { yang signifikan }\end{array}$ \\
\hline$\rho_{Y X 2}$ & 0,313 & 2,878 & 0,005 & Ho ditolak, terdapat pengaruh \\
& 0,453 & 4,166 & 0,000 & yang signifikan \\
\hline
\end{tabular}

Sumber : Hasil perhitungan statistik (terlampir).

Dari tabel 4.28 didapat hasil sebagai berikut :

a. Untuk pengaruh parsial kualitas pelayanan $\left(\mathrm{X}_{1}\right)$ terhadap kepuasan masyarakat $(\mathrm{Y})$, nilai Sig. $(0,005)<\alpha(0,05)$ maka Ho ditolak. Dengan demikian dapat disimpulkan bahwa kualitas pelayanan secara parsial berpengaruh signifikan terhadap kepuasan masyarakat.

b. Untuk pengaruh parsial biaya pelayanan jasa pernikahan $\left(\mathrm{X}_{2}\right)$ terhadap kepuasan masyarakat (Y), nilai Sig. $(0,000)<\alpha(0,05)$ maka Ho ditolak. Dengan demikian dapat disimpulkan bahwa biaya pelayanan jasa pernikahan secara parsial berpengaruh signifikan terhadap kepuasan masyarakat.

\section{Pengujian Pengaruh Secara Simultan Variabel $X_{1}$ dan $X_{2}$ Terhadap Y}

Hasil uji statistik pengaruh kualitas jasa pelayanan perbankan dan kepuasan nasabah secara simultan terhadap loyalitas nasabah dengan menggunakan hipotesis sebagai berikut :

$\mathrm{H}_{\mathrm{O}}: \rho_{\mathrm{YX} 1}=\rho_{\mathrm{YX} 2}=0 \rightarrow$ Tidak terdapat pengaruh bersamaan dari variabel independen $\mathrm{X}$ terhadap variabel dependen $\mathrm{Y}$

$\mathrm{H}_{1}: \rho_{\mathrm{YX} 1} \neq \rho_{\mathrm{YX} 2} \neq 0 \rightarrow$ Terdapat pengaruh secara bersamaan dari variabel independen $\mathrm{X}$ terhadap variabel dependen $\mathrm{Y}$.

Dengan kriteria uji : Tolak Ho jika Sig. $<\alpha$ atau $F_{\text {hitung }}>F_{\text {tabel. }}$.

\section{Tabel 5}

Pengaruh Simultan Variabel X Terhadap Y

\begin{tabular}{|c|c|c|c|}
\hline Model & F-hitung & Sig. & Kesimpulan \\
\hline$\rho_{\mathrm{YX}}$ & 26,207 & 0,000 & Ho ditolak, terdapat pengaruh yang signifikan \\
\hline
\end{tabular}

Sumber : Hasil perhitungan statistik (terlampir).

Dari tabel 5 di atas terlihat bahwa nilai Sig. sebesar 0,000 yang lebih kecil dari $\alpha(0,05)$. Dengan demikian Ho ditolak sehingga dapat disimpulkan bahwa kualitas pelayanan $\left(\mathrm{X}_{1}\right)$ dan biaya pelayanan jasa pernikahan $\left(\mathrm{X}_{2}\right)$ secara simultan berpengaruh signifikan terhadap kepuasan masyarakat (Y). 


\section{KESIMPULAN dan SARAN}

Kesimpulan

Kesimpulan yang didapatkan dalam penelitian ini yaitu :

1. Untuk pengaruh parsial kualitas pelayanan $\left(\mathrm{X}_{1}\right)$ terhadap kepuasan masyarakat $(\mathrm{Y})$, nilai Sig. $(0,005)<\alpha(0,05)$ maka Ho ditolak. Dengan demikian dapat disimpulkan bahwa kualitas pelayanan secara parsial berpengaruh signifikan terhadap kepuasan masyarakat.

2. Untuk pengaruh parsial biaya pelayanan jasa pernikahan $\left(\mathrm{X}_{2}\right)$ terhadap kepuasan masyarakat (Y), nilai Sig. $(0,000)<\alpha(0,05)$ maka Ho ditolak. Dengan demikian dapat disimpulkan bahwa biaya pelayanan jasa pernikahan secara parsial berpengaruh signifikan terhadap kepuasan masyarakat.

3. Nilai Sig. sebesar 0,000 yang lebih kecil dari $\alpha(0,05)$. Dengan demikian Ho ditolak sehingga dapat disimpulkan bahwa kualitas pelayanan $\left(\mathrm{X}_{1}\right)$ dan biaya pelayanan jasa pernikahan $\left(\mathrm{X}_{2}\right)$ secara simultan berpengaruh signifikan terhadap kepuasan masyarakat $(\mathrm{Y})$.

Saran

1. Kualitas pelayanan KUA Kecamatan Cikampek Karawang harus di jaga agar masyarakat merasa puas terhadap pelayanan yang diberikan

2. Bagi penelitian lain yang ingin melanjutkan penelitian ini agar menambah variabel penelitiannya lebih dari satu variabel sehingga hasilnya dapat digeneralisasikan.

3. Diharapkan hasil penelitian ini dapat dijadikan sebagai bahan referensi untuk penelitian berikutnya.

\section{DAFTAR PUSTAKA}

Giese dan Cote,2000, Academi Of Marketing Science Review. Defining Consumer satisfaction, Volume 2000, No 1.

Husain Umar, 2009, Metodologi Penelitian, Aplikasi Dalam Pemasaran, Jakarta : PT Gramedia Pustaka Utama. 
Dedi Mulyadi

Vol 5 No 1

ISSN : 2541-6995

E ISSN : 2580-5517

Kotler, Philip, an Keller,Kevin Lane,2009, Manajemen Pemasaran,Edisi 12, Jakarta: PT Indeks Kelompok Gramedia.

Leonasd L. Barry, Parasuraman, and Valerie A Zeithaml, 1988, Servqual : A Multiple Item Scale For Measuring Consumer Perception Of Service. Journal of Retailing Vol 64 No 1.

Sugiono, 2007, Metode Penelitian Kuantitatif Kualitatif dan R\&D, Bandung : CV Alfabeta. 